\title{
Työelämän muutos ja aikuiskoulutus
}

\begin{abstract}
Julkunen, Raija 1987. Työelämän muutos ja aikuiskoulutus, Aikuiskasvatus 7, 3, 100-105. - Suomalaisessa julkisuudessa keskustellaan nykyisin kahdesta kysymyksestä, jotka sivuavat työelämän tutkimusta: rakennemuutoksesta ja työelämän uudistamisesta. Nämä kaksi teemaa leikkaavat mm. niissä muutoksissa, joita tapahtuu ja joita tavoitellaan yritysten organisaatiossa, johtamismenetelmissä, työvoiman käytössä ja työelämän suhteissa. Kumpikin niistä asettaa haasteita myös aikuiskoulutukselle. Tässä artikkelissa tarkastellaan näitä ajankohtaisia kysymyksiä työelämän tutkimuksen valossa.
\end{abstract}

\section{Rakenteellinen muutos}

Saatuaan vasta päätökseen "vanhan" rakennemuutoksen - sen jossa Suomesta tuli avoin ja elinkeinorakenteeltaan uudenaikainen kansantalous - Suomi on joutunut uuteen rakennemuutokseen taas hieman myöhäissyntyisesti. Sitä luonnehtivat yritystoiminnan ja teollisuuden uudelleenjärjestäytyminen omistuksellisesti, tuotantorakenteen, teknologian, sijainnin jne. suhteen, yritysten kansainvälistyminen sekä kansainvälisen rahan kasvava vaikutus kansantalouteen. Siihen kuuluu myös murros yritysten ja työn organisaatiossa, työvoiman käytössä ja työelämän suhteissa. Kysymys on koko kapitalistista maailmaa ravistavasta murroksesta, jolle sosiologinen tutkimus on tarjonnut erilaisia (myös keskenään ristiriitaisia) kokonaisselityksiä:

— siirtymän teollisesta jälkiteolliseen tai tietoyhteiskuntaan

- kapitalismin vaiheteoriat, joiden mukaan elämme siirtymää vanhasta kehitystavasta uuteen

— pitkien aaltojen teoriat, joiden mukaan elämme pitkän aallon laskupuoliskoa

- muita teorioita suurista rakennekriiseistä tai yhteiskunnan muutoksista.

Yhteistä useille näistä teorioista on näkemys siitä, että yhteiskunnassa tapahtuu ajoittain tavanomaista syvällisempää uudelleenra-

1 Lyhennetty versio palkansaajajärjestöjen aikuiskoulutusseminaarissa 28.8.1987 pidetystä alısstuksesta. kenteistumista, uuden kehitystavan muotoutumista, jollaisella on myös historiallisia vertauskohtia. Yhtäältä uudelleenrakenteistuminen on sidoksissa pääoman kannattavuus- ja tuottoehtoihin, mutta samalla uudelleenrakenteistumisen aikoina käydään myös taistelua yhteiskunnallisen kehityksen suunnasta (Julkunen 1987).

Edellisistä poikkeavan näkökulman tämän päivän työelämään tarjoaa saksalainen keskustelu työyhteiskunnan kriisistä tai eroosiosta (ks. Aho 1987). Sellaisessa kypsässä palkkatyön yhteiskunnassa, missä elämme työ on ihmiselle paitsi toimeentulopakko, myös heidän identiteettinsä, kansalaisuutensa ja yhteiskunnallisen asemansa perusta. Työ on myös juurrutettu ideologisesti määrittelemällä se velvollisuudeksi, oikeudeksi ja/tai tarpeeksi. Työyhteiskunnan eroosioväitteissä on viitattu: — joukkotyöttömyyteen

- pysyvään työn supistumisen tendenssiin teknologisen kehityksen seurauksena

- palkkatyön kanssa vaihtoehtoisiin toimeentulomuotoihin (hyvinvointivaltio, vaihtoehtoyhteisöt, omatyö)

— työn sisällölliseen köyhtymiseen ja vierasmääräämiseen työssä

- arvokumouksen (toimeentuloarvoista itsetoteutuksellisiin)

— yhteiskunnallisten ristiriitojen ja liikkeiden uudelleenmuotoutumiseen (uudet liikkeet, uudet konfliktirintamat vanhan luokkajakoristiriidan tilalle)

- normaalityösuhteen hajoamiseen (tilalle väliaikaisia, tilapäisiä, osa-aikaisia jne. työsuhteita) 
Näkemyksen mukaan työ ja palkkatyö on kadottamassa painoarvonsa sekä yhteiskunnan rakenneperiaatteena, sosiaalisten suhteiden lähteenä että yksilöiden elämän keskuksena. Myös työn ideologia kuihuu. Näkymä on esitetty myös utopiana vapautumiseksi palkkatyön pakkovallasta. Tällöin ammattiyhdistysliike on näyttäytynyt jäänteenä, joka oman valtansa säilyttämiseksi tarrautuu vanhaan eikä pysty johtamaan kehitystä pois palkkatyön yhteiskunnasta.

Oma näkemykseni on kuitenkin toinen. Näkyvissä olevassa tulevaisuudessa ansiotyö säilyy toimeentulopakkona, ihmiset sosiaalistuvat edelleen palkkatyöläisiksi, taistelevat edelleen työpaikoista ja paremmmista työehdoista pikemmin kuin jostain muusta sosiaalisesta järjestyksestä. Irtaantumista palkkatyön determinoivasta voimasta elämäntavan suhteen tapahtuu kyllä. Työn määrittäminen pakkona ja velvollisuutena ei riitä enää sen moraaliseksi juurruttamiseksi. Työn normatiivinen juurruttaminen oikeutena ja tarpeena puolestaan edellyttää työelämän kehittymistä suuntaan, jossa työ voidaan käsittää oikeaksi elämäksi, jossa voi käyttää ja toteuttaa itseään. Mielestäni sellaisia kehityssuuntia onkin nähtävissä.

Työelämän tutkimus tarjoaa täten näkökulmia rakennemuutoksen kokonaisuuden ja tulevaisuuden hahmottamiseksi. Nämä voivat olla myös keskenään ristiriitaisia. Esimerkiksi koulutuksen suhteen vaikkapa tietoyhteiskunnan ja työyhteiskunnan eroosion teoriat tarjoavat aivan vastakkaisia johtopäätöksiä. Tietoyhteiskunnan teoria korostaa nimenomaan tuotannossa tarvittavaa tietoa - tietoa tuotantoresurssina; työyhteiskunnan eroosion teoriat taas kehottavat luomaan edellytyksiä ihmisten autonomiselle toiminnalle yhteiskunnallisen työn ulkopuolella, josta sen näkemyksen mukaan muodostuu ihmisten keskeinen elämänintressi, työn yhä vain "banalisoituessa" (André Gorzin termein).

Työelämän tutkimus on kiinnostunut myös itse rakennemuutoksen prosessista ja sen sosiaalisista seurauksista, sopeutumisongelmista ja kansallisista strategioista tässä. Tosin Suomessa on ällistyttävän vähän tutkittu esimerkiksi teollisuuden rakennemuutoksen vaikutuksia, työmarkkinoiden sopeutumisprosessia ja yksilöllisiä seurausvaikutuksia tai keskusteltu rakennemuutoksen hallinnan mahdollisuuksista ja keinoista. Tässä suhteessa $\mathrm{mm}$. ruotsalainen tutkimus on ollut paljon vilkkaampaa, kuten on ollut myös rakennemuutoksen sosiaalisia seurauksia hoitava politiikkakin. Ruotsissahan kehitettiin 1970-luvul- la hyvin kattava selektiivinen yritystoiminnan tuki- ja työmarkkinapolitiikka estämään rakennemuutoksen sosiaaliset haitat ja sitouduttiin vahvasti työllisyyden ylläpitoon. Eräs tutkimuksen kohde on luonnollisesti tämän politiikan seurausten arviointi (ks. Haapola 1986).

Tutkimus voi myös valaista rakennemuutoksen hallinnan ongelmaa yhteiskunnallisesti omaksuttujen tavoitteiden puitteissa. Esimerkiksi Suomessa hyväksytään laajasti rakennemuutoksen välttämättömyys. Samalla olemme kuitenkin hyväksyneet sosiaalisen oikeudenmukaisuuden arvoja. Näistä lähtökohdista käsin tarvitaan McKersien ja Sengenbergerin (ks. Haapola 1986) integroivaksi sopeuttamiseksi kutsumaa strategiaa, joka yhdentää taloudelliset ja sosiaaliset näkökohdat. Työllisyyden näkökulmasta on tarkoituksenmukaista tarkastella rakennemuutosta sisäinen - ulkoinen ulottuvuudella. Sisäisellä sopeutumisella tarkoitetaan uusiin tuotteisiin tai teknologiaan siirtymistä tai voimavarojen tehokkaampaa hyödyntämistä saman tuotantolaitoksen puitteissa. Ulkoisella sopeutumisella taas vanhojen tuotantolaitosten lakkauttamista ja uusien perustamista tai syntymistä. Tällöin sopeutumisprosessi heijastuu ulkoisilla työmarkkinoilla. Kumpaakin sopeuttamista voidaan edistää koulutuksen avulla. Työntekijöiden kannalta inhimillistä on, että sopeutuminen mahdollisimman suuressa määrin tapahtuu sisäisenä sopeutumisena, yrityksen sisäisillä työmarkkinoilla. Tätä vaatii jo yrityksen sosiaalinen vastuu työntekijöistään.

Yrityksen koulutusprojektein voidaan tehostaa yrityksen elinvoimaisuutta ja nostaa kannattavuutta, henkilöstön täydennyskoulutus voidaan sijoittaa antisyklisesti (estämään suhdanteiden vaikutuksia), uudelleentyöllistäminen voi nojata koulutukseen ja koulutusprojekteja voidaan käyttää osana taantuvien paikkakuntien alueellista kehittämistä. McKersie ja Sengenberger arvioivat integroidun sopeutuspolitiikan toimineen parhaiten kooperatiivisten työelämän suhteiden vallitessa, siellä missä yritysjohto on tarjonnut työntekijöille tietoa ja osallistumismahdollisuuksia ja ay-liike on pääosin ottanut myönteisen suhteen rakennemuutokseen.

Rakennemuutoksen kiihtyminen on nostanut ajankohtaiseksi tutkimuskohteeksi myös työmarkkinoiden toimintatavan, työmarkkinoiden kyvyn allokoida työvoimaa, työmarkkinoiden jouston, ammatillisen jouston jne.

Kansainvälisissä keskusteluissa työmarkkinoiden ja talouden joustosta (ks. esim. Labour market flexibility 1987, OECD 1986) kou- 
lutus ei ole mitenkään keskeisesti esillä. OECD:n tutkimuksissa on erotettu neljää eri jouston muotoa:

1. Palkkajousto eli palkkojen ja epäsuorien työvoimakustannusten sopeutuminen taloudellisiin vaihteluihin ja yrityksen menestymiseen. Eräs esimerkki tästä ovat ammattiliittojen kanssa sovitut myönnytyssopimukset.

2. Määrällinen jousto eli työvoiman määrän sopeuttaminen suhdanteisiin välineenä vaihtelevat työsuhdetyypit (tilapäiset ja määräaikaiset työsuhteet, vuokratyövoima, alihankintojen sisäistäminen ja ulkoistaminen) sekä työsuhdeturvan heikentäminen.

3. Teknis-organisatorinen joustavuus tarkoittaa yrityksen kykyä jatkuvaan innovatiivisuuteen sekä tuoterakenteen ja volyymin sopeuttamista markkinoihin.

4. Työaikajousto, joka sisältää useita erilaisia yritysten tarpeita: suhdanne- ja sesonkisidonnaisen työajan, käyntiaikojen pidentämisen työaikojen monipuolistamisen avulla, sopeutumisen päivittäisiin ja viikoittaisiin kuormitushuippuihin.

Kaksi ensimmäistä jouston muotoa törmäävät suoraan palkansaajien etuja vastaan. Niiden kokonaisyhteiskunnalliset seuraukset ovat myös kyseenalaisia. Esimerkiksi Yhdysvalloissa ne ovat edistäneet matalapalkkaisen, epävakaan, osa-aikaisen ja naisvaltaisen työllisyyden syntyä palveluissa. Sen sijaan kahdessa jälkimmäisessä on nähty mahdollisuus eri intressien yhteensovittamiseen. Myönteisimmät seuraukset palkkatyöläisten kannalta voi olla teknisorganisatorista joustavuutta korostavalla yritysstrategialla.

Koulutuksen suhde joustoon ei ole yksiselitteinen. Ammatillisen koulutuksen ja tutkintojen kasvu lisännee halukkuutta päästä omaan ammattiin ja pysyä siinä. Ammatillisen koulutuksen laajentuminen on vähentänyt sellaista "jokamiestyövoimaa", joka on vailla ammatillista identiteettiä ja jota voidaan liikutella työmarkkinoiden tarpeiden mukaan. Tosin laajaalainen ammattikoulutus tukee liikkumista ammatin sisällä, lähiammatteihin ja uusiutumiskykyä omassa ammatissa. Samoin aikuiskoulutuksella voidaan edistää sekä työmarkkinoiden joustavuutta (elinikäinen koulutus, uudelleenkoulutus) että yritysten teknis-organisatorista joustavuutta.

\section{Yrityksen ja työn organisaatio; työvoiman käyttö ja työelämän suhteet}

Sosiaali- ja yritystieteet ovat täynnään erilaisia johtamis- ja organisaatio-oppeja, joissa on sama perustavoite: miten ylittää kapitalismin perusristiriita, intergroida työntekijät toisten omistamiin yrityksiin, tehdä heistä lojaaleja yritykselle sekä sitouttaa työhönsä ja yritykseen. Useimmissa opeissa on hyvinkin humanistinen ote ja ne antavat ohjeita siitä, miten demokraattisella johtamistyylillä, sisäisellä viestinnällä, töiden muotoilulla jne. voidaan tavoitetta edistää. Näiden oppien perusteella voisi saada kuvan, että jo puhdas tehokkuus vaatii inhimillistä yritysilmastoa, tyydyttäviä työoloja, haasteellisia ja monipuolisia työn sisältöjä (ks. Alvesson 1987). Työelämän todellisuus - sitä enemmän mitä alemmas organisatorisessa hierarkiassa mennään, on kuitenkin ollut kaukana näistä opeista. Näin on erityisesti Suomessa, jota syystä on kutsuttu "hierarkisten rakenteiden ulkomuseoksi" - mihin lisäisin epäluottamukseen nojaavat tuotannolliset suhteet.

Kansainvälisessä työn sosiologiassa elää kuitenkin varsin vahvana käsitys, että tätänykyä työn organisaatiossa, työvoiman käytössä ja työelämän suhteissa olisi tapahtumassa laadullinen murros: siirtymä tayloristisista rationalisointikäsityksistä uusiin, siirtymä vastakkaisten etujen työsuhteista kooperatiivisiin, siirtymä työvoiman autoritaarisesta kohtelusta demokraattisempaan jne. Diagnoosi on tehty oireiden ja merkkien, ei minkään maan keskimääräisen todellisuuden perusteella - ja voihan se osoittautua vääräksi, kuten ennusteille joskus käy. Eivätkä sosiologit toki ole yksimielisiä siitä, miten näkyvissä olevat merkit pitäisi tulkita. Jos ammattiliitot esimerkiksi suostuvat herkemmin samastumaan yritysten etuihin (tuottavuussopimukset, myönnytykset saavutetuissa eduissa jne.), voidaan se tulkita paitsi uusien kooperatiivisempien suhteiden yleistymiseksi, myös yksinkertaisesti ammattiliittojèn heikkoudeksi nykyisessä taloudellisessa ja työllisyystilanteessa.

Työvoiman käytössä ja työn organisoinnissa on tapahtumassa seuraavanlaisia muutoksia:

- johdon kontrolli- ja valvontatehtävät supistuvat suoritustason itseohjaavuuden tai itsevalvonnan hyväksi

- uusien hierarkisten portaiden synty organisaatioihin on pysähtynyt tai kääntynyt niiden karsimiseksi 
— työnjohdolliset tehtävät muuttuvat valvovista tukea antaviksi

— yritysjohto ottaa käyttöön erilaisia ohjelmia ja aloitteita työntekijöiden osallistamiseksi tuotantokysymyksiin ja sitouttamiseksi yritykseen

- tehtaan lattiatason toimintoja integroidaan

- työtehtäviä ja ammattikuvia laajennetaan ja erilaisia pätevyyksiä yhdistetään: äärimmäisestä erikoistumisesta työssä kiertoon, tehtävien laajentamiseen ja moniammattisuuteen

- henkilökohtaisille ominaisuuksille asetetaan lisää painoa työvoiman valikoinnissa, uudenlaisia kompetensseja korostetaan (joustavuutta, sosiaalista taitavuutta, oikeaa persoonallisuutta moniin tehtäviin)

- ryhmätyö ja ryhmävastuu yleistyy (esim. Bäcklund 1985, Gustavsen 1986, Julkunen 1987):

Rohkeimmin taylorismin hautaamista ovat julistaneet saksalaiset Kern \& Schumann (1984), samat tutkijat, jotka 1960-luvun lopun aineistojen nojalla päättelivät automaatioasteen nousun johtavan työn polarisointiin. Uuden tutkimuksensa saksalaisen teollisuuden ydinaloilta he otsikoivat "Työnjaon loppu?" ja kiteyttävät päätulokset väitteisiin "uusista tuotantokäsityksistä", "uudeksi käsitykseksi èlävästä työstä" ja "teollisuustyön uudelleenammatillistamisesta". Uudet tuotantokäsitykset nojaavat kaikkien lattiatason voimavarojen hyväksikäyttöön, mikä on mahdollista, kun työvoimaa käytetään "ideologiattomasti" - ts. kun pääoman herruutta ei tarvitse ,enää lujittaa autoritaarisella johdolla ja rajoittavalla työn muotoilulla. Sen sijaan tutkimiltaan kriisialoilta Kern \& Schumann eivät löydä merkkejä laadullisesti uudesta työvoiman käytöstä. Niinpä uhkaamassa onkin teollisuustyövoiman kahtiahalkeaminen rationalisointivoittajiin ja -häviäjiin.

Mm. Björn Gustavsen (1986) on ennakoinut perinteisen pyramidimallisen yritysrakenteen muuttuvan vaateripustin-malliseksi. Ylin johto laajenee ja sen työprosessi tulee kollektiivisemmaksi, hierarkian keskitasot supistuvat ja tärkeimmät toiminnot sijoitetaan tuotannon tasolle ja yhdennetään siihen. Yritystä johtaa kollektiivinen johto ja tuotannosta vastaavat monitaitoiset, itseohjautuvat, kustannus- ja laatuvastuiset ryhmät. Suora dialogi ylimmän johdon ja suoritusportaan välillä yleistyy.

Tapahtumassa olevat muutokset voi tulkita osaksi rakenteellista murrosta, pitkien aaltojen tai vaiheterioiden mukaista uudelleenrakenteistumista. Monet yhteiskunnalliset ja taloudelliset tekijät pakottavat yrityksiä ja organisaatioita kehittämään toimintaansa suuntaan, joka mahdollistaa jatkuvan innovatiivisuuden, joustavuuden, asiakas- ja markkinakeskeisyyden, korkean laadun jne. Yksilöidymmin muutokset työvoiman käytössä ja työn organisaatiossa nousevat seuraavanlaisista tekijöistä:

- uusista markkina- ja tuotantostrategioista (esim. Pioren \& Sabelin (1984) korostama joustava erikoistuminen)

- uusista johtamistyyleistä (demokraattisempi, osallistuvampi, vähemmän autoritaarinen)

- uusista yritysrakenteista (esim. byrokratian ja hierarkisten tasojen purkaminen, tulosvastuun hajautus)

- uusista valmistusjärjestelmistä (esim. joustavat valmistusjärjestelmät)

- uudesta tietotekniikasta (se antaa suuremman pelivaran työn organisoinnin suhteen, mutta se edellyttää myös sosiaalisia innovaatioita, jotta siitä saataisiin suurin hyöty)

- uusista tuotantofilosofioista (esim. japanilaistyyppinen just-in-time, ei-varastoja, nolla-virhettä-"filosofiat")

- uusista sosiaalisista suhteista ja "näkymättömistä sopimuksista" tehtaan lattialla (johdon muuttunut käsitys työmiehestä, jota ei enää koeta häiriönä ja uhkana; suuremman luottamuksen suhteet)

- rationalisointistrategioiden uudenlaisesta kohdistumisesta (ei enää vain suorittavan työn voimaperäistämiseen vaan koko yritysrakenteeseen, erilaisten osaprosessien integrointiin ja yritysten välisiin suhteisiin) - uusista rationalisointikäsityksistä (esim. moniammattisuus ja toimintojen yhdistäminen äärimmäisen osittelun sijaan).

En tarkoita väittää, että näkyvissä olevat muutokset - jotka siis nousevat yritysten intresseistä - tuottaisivat yksiselitteisesti palkkatyöläisten tavoittelemaa parempaa työelämän laatua. Niiden seuraukset, etenkin kun otetaan huomioon rakennemuutoksen työvoimaa syrjäyttävä puoli, voivat olla hyvinkin eriytyneitä työnjaon, luokka- ja sukupuolirakenteen eri osissa. Muutokset saattavat myös asettaa eri ryhmät toisiaan vastaan: samat piirteet jotka voivat ammattillistaa ja kokonaistaa lattiatason työtä voivat olla uhkaavia keski- ja työnjohdolle. Työntekijät voivat vastustaa sellaista kehitystä kohti vaativampaa työtä, joka työpsykologisten teorioiden mukaan vastaa heidän tarpeitaan. Teoriat vaativampien ja monipuolisempien työtehtävien autuaaksitekevästä luonteesta eivät ota huomioon lattiatason todellisuutta, sitä miten monimutkaisten neuvottelujen, sopeutumisten ja sosiaalisten asemien lukkoonlyönnin tulos sopu työprosessissa on ja miten työntekijät arvioivat muutoksia sen suhteen, "kenen oma muutos on". Mutta vähintäänkin murros tarjoaa haasteita 
ammattiyhdistysliikkeelle ja parhaimmillaan tarttumakohtia työelämän demokratisoimiseksi.

\section{Työelämän demokratisointiin?}

Työelämän demokratisointi on yhteiskunnallisen kamppailun kysymys. Tutkimus voi kuitenkin valaista erilaisia työelämän suhteiden malleja, niiden edellytyksiä ja seurauksia. Vaatimattomimmillaan tutkimus - kuten Suomessa paljolti - voi tyytyä asenteellisten edellytysten kartoittamiseen. Muissa Pohjoismaissa on pitkä kokeilevien ja konsultoivien kenttäprojektien perinne, jolla on ollut varsin selvä vaikutus yritysdemokratiauudistuksiin sekä Norjassa että Ruotsissa. Suomessa tämänkaltaiselle tutkimukselle ei ole ollut edellytyksiä. Ruotsissa on myös Suomea vahvempi työntekijöiden opintokerhomuotoinen tutkijoiden tukema opiskelu- ja tutkimusperinne, jossa työntekijät ovat tutkineet omaa työtään ja yritystään ja joka on luonut edellytyksiä mm. vastasuunnitelmille saneerausten tai teknologis-organisatoristen uudistusten yhteydessä.

Etenkin aikaisemmin tutkijat ovat pyrkineet juurruttamaan työelämään valmiita malleja (tiettyjä osallistumisjärjestelmiä, sosioteknisiä työn organisointia tms.). Björn Gustavsen on kuvannut tämän lähestymistavan heikkouksia. Tällä hetkellä hän näkee tutkimuksen tehtäväksi edistää organisaatioiden kykyä uudistumiseen ja muutoksen infrastruktuurin luomista. Organisatorinen uudistuminen vaatii sosiaalisten suhteiden verkostoa, kykyä "demokraattiseen dialogiin", kykyä "haistaa" kehityssuuntia, kokeilla näitä, jatkuvaa koulutusta ja kasvatusta jne. Tutkimuksen tehtävä tällä hetkellä on pikemmin varustaa työelämän osapuolet uudistumiskyvyn edellyttämällä tiedolla kuin tarjota valmiita organisatorisia malleja.

Tällä hetkellä työnantajilla on tarve vetää työntekijät entistä selvemmin mukaan kannattavuus- ja tuottavuuskysymyksiin sekä päästä suoraan keskusteluyhteyteen työntekijöiden kanssa (Framtidsfrågor på arbetsplatsen 1984). Tämä voi tapahtua joko sivuuttamalla ammattijärjestöt, ääritapauksessa pyrkimällä niiden eliminointiin (työsuhteiden amerikanisointi) tai sitouttamalla ammattiyhdistykset yrityksen näkökohtiin. Ammattiyhdistykset voivat vastata tähän periaatteessa kolmella tavalla:
1. ne voivat vetäytyä ja rajoittua perinteisiin työehtokysymyksiin (perinteinen brittiläinen malli)

2. ne voivat sitoutua "oman" yrityksen menestykseen (työsuhteiden japanisointi)

3. ne voivat pyrkiä yhdistämään sitoutumisen demokraattisten uudistusten tavoitteluun, ts. laajentaa työntekijöiden demokraattisia oikeuksia vaikuttaa koko yrityspolitiikkaan sekä teknologisiin ja organisatorisiin uudistuksiin (työsuhteiden ruotsittaminen).

Tällä hetkellä on kansainvälisesti katsoen vahvaa painetta sellaisiin konsultointi- ja osallistumisjärjestelmiin, jotka sivuuttavat ammattiyhdistykset ja ylipäätänsä ammattiyhdistysten harjoittaman työvoiman käytön (byrokraattisen) valvonnan purkamiseen. Toisaalta on esimerkkejä siitä, miten työelämän uudistamiseen tähtäävän politiikan edellyttämää dialogia on rakennettu nimenomaan ammattiyhdistysten kanssa (Julkunen 1987).

Työntekijöiden osallistumisjärjestelmissä yhdistyy aina kaksi intressiä: työnantajien intressi sitouttaa työntekijät yritykseen, vähentää muutosvastarintaa ja käyttää kokonaisvaltaisemmin työntekijöiden pätevyyttä. Sitoutuminen työhön ja täydellisempi itsensä ja tietojensa käyttö työssä entistä demokraattisemmassa ilmapiirissä on jo sinänsä työntekijöidenkin etujen mukaista. Mutta lisäksi he osallistumiskanavien kautta ajavat omia näkökohtiaan (mm. työllisyyden, teknologisten ja organisatoristen muutosten sisällön suhteen). Työntekijöiden oman näkökulman turvaaminen yritysdemokratiajärjestelmissä ei ole yksinkertainen asia. Se edellyttää paitsi muodollisia kanavia myös tosiasiallista aktiivisuutta, kiinnostusta, näköaloja, tietoja jne. Vaikuttamisen resurssit ovat hyvin epätasaisesti jakautuneita silloinkin, kun muodolliset kanavat osallistumiselle ovat olemassa. Niinkuin aina vaikuttaminen vaatii aktivisteilta paljon opiskelua ja tietoa sekä lisäksi tuekseen laajaa mobilisoitumista asioiden taakse. Ammattiyhdistysliikkeen perinteinen osallistumismuoto, joka on vakiintunut työehtojen valvontaan, ei toimi uusissa haasteissa.

Työelämän uudistusten mallia on meillä haettu Ruotsista, missä 1970-luvulla toteutettiin todella mittava työelämän reformien sarja. Ruotsissa on myös kartoitettu kokemuksia myötämääräämislainsäädännöstä ja muista yd-järjestelyistä. Ja kysytty $\mathrm{mm}$. merkitseekö lisääntyvä ammattiyhdistysliikeen osallistuminen myös lisääntyvää vaikuttamista? Mitä seurauksia ammattiyhdistysten uudesta roolista on yrityksille (vrt. kaikki pelot ja vastarinta)? Laajan v. 1983-84 suoritetun kartoituksen (Bergren 1986) mukaan suuri enemmistö yh- 
tiöiden huippujohdosta pitää ammattiyhdistysten lisääntynyttä osallistumista myönteisenä eikä katso, että myötämäärääminen olisi este päätöksenteolle tai veisi liikaa aikaa ja voimavaroja. Kuitenkin huippujohto ja ammattiyhdistykset katsovat yhtäläisesti strategisten päätösten säilyneen omistajien ja yritysjohdon käsissä ja ammattiyhdistysten osallistumisen olevan luonteeltaan melko passiivista ja heikkoa. Yritysjohto oli varsin tyytyväinen ammattiyhdistysten vaikutuksen nykyiseen muotoon. Sen sijaan sekä työntekijöiden että toimihenkilöiden ammattiyhdistykset haluaisivat lisää tosiasiallista vaikuttamista. Kuitenkin silloin kun ammattiyhdistykset ovat voineet tosiasiallisesti vaikuttaa päätöksiin arvioivat sekä johtajat että ammattiyhdistykset sen vieneen asioita myönteiseen suuntaan.

Tutkimus ei tue työnantajien pelkoja yritysdemokratian suhteen. Suurin vaara lakisääteisten osallistumisjärjestelmien suhteen on niiden jääminen pelkiksi paperitiikereiksi, jotka vain kanavoivat yhteiskunnassa syntyneen reformipaineen tai - Suomen tapauksessa olisivat ulospäin osoitus Suomen lopullisesta modernisoitumisesta. Uudistusten tosiasiallinen vaikuttavuus on luonnollisesti paitsi valtakysymys myös suuri koulutuksellinen haaste. Tällaisen koulutuksen tulisi tukea työntekijöiden mobilisoitumista, kiinnostumista vaikuttamiseen, tietoa yrityksistä jne., ts. olla sekä tiedon lisääntymisen että mobilisoitumisen väline.

\section{Kirjallisuus}

Aho, Simo: Palkkatyön yhteiskunnan kehitysvaiheet. Lisensiaattitutkimus sosiologiassa. Tampere 1987.

Alvesson, Mats: Organization Theory and Technocratic Consciousness. Berlin: Walter de Gruyter, 1987.

Bergren, Christian: Top Management and Codetermination in Swedish Companies: Greater Union Influence Results in Better Decisions. Economic and Industrial Democracy 1986, 7, 1, 99-108.

Bäcklund, Ann-Katrin: Kompetens för ett arbetsliv i förändring - utvecklingstendenser som kan revolutionera arbetslivet. Malmö: Institutionen för pedagogik, Lärärhögskolan, Nr 450, 1985.

Gorz, André: Wege ins Paradies. Berlin: Rotbuch Verlag, 1983.

Gustavsen, Björn: Evolving Patterns of Enterprise Organisation: The Move Towards Greater Flexibility. International Labour Review 1986, 125, 4, $367-382$.

Flexibility in the Labour Market. Paris: OECD, 1986.

Framtidsfrågor på arbetsplatsen. Front-projekt. Arbetslivscentrum, 1984.

Haapola, Ilkka: Teollisuuden rakennemuutos ja työmarkkinoiden sopeutumisongelmat. Työvoimaministeriö, Työvoimapoliittisia selvityksiä Nr. 68, 1986.

Julkunen, Raija: Työprosessi ja pitkät aallot. Tampere: Vastapaino 1987.

Kern, Horst \& Schumann, Michael: Das Ende der Arbeitsteilung? München: Verlag C.H. Beck, 1984.

Labour Market Flexibility. Labour and Society 1987, 12,1 .

Piore, Michael \& Sabel, Charles: The Second Indrustial Divide. New York: Basic Books, 1984. 


\section{AIKUISKASVATUS}

\section{The Finnish Journal of Adult Education}

Vol 7, 3/1987

ISSN 0358-6197

Summary

Julkunen, Raija 1987. Changes in work life and adult education.

Two matters appear to dominate public debate in Finland at the present: structural change and reformation of work life. These themes intersect, for example, in changes which occur and are aimed at in the organizations, management methods, labour utilization and work life relationships in enterprises. Both also provide challenges to adult education. This article looks at these matters in the light of research carried out in work life. 